\title{
O twórczym przekraczaniu granic. Przetworzenia i reprezentacje w przestrzeni sztuki
}

\begin{abstract}
Szczęsna Ewa, O twórczym przekraczaniu granic. Przetworzenia i reprezentacje w przestrzeni sztuki [On creative border crossing. Transformations and representations in art]. „Przestrzenie Teorii" 31. Poznań 2019, Adam Mickiewicz University Press, pp. 209-225. ISSN 1644-6763. DOI 10.14746/pt.2019.31.11.
\end{abstract}

The paper analyzes the thesis that constantly transgressing boundaries in art is a fundamental principle and essential condition for artistic progress. Crossing external (the art - other discourses) and internal (between various art genres) boundaries is analyzed on the basis of transformations (especially adaptation) and representations. Dialogue relations initialized by art crossing the boundaries are analyzed as well: reinterpretations, polemics, extensions and supplementations. There is also a discussion of the ways in which semiotic and media boundaries are trangressed, especially the semiotic and media borders that are essential for the semiotic sphere of one artistic genre for the semiotic and media sphere of the other. The article refers to examples taken from literature, film, sculpture and painting.

KEYWORDS: adaptation, representation, transformation, digital art, theory of literature, theory of art

Sztuka to forma

Jean Baudrillard

Granice zewnętrzne sztuki - oddzielające to, co nią jest, od tego, co nią nie jest - wyznaczane sa przez własności, które określają jej istotę i warunki, jakie musi spełnić przedmiot, by mógł być uznany za jej przedmiot. Cechami, które organizują ontyczność utworów sztuki, są kreacja artystyczna i dominacja ukierunkowania estetycznego. Utwory uznawane za arcydzieła muszą dodatkowo spełniać warunek oryginalności. To sprawia, że postęp sztuki (jeśli można użyć tej kategorii w odniesieniu do dziania się sztuki) dokonuje się w postawie przełamywania tego, co powtarzalne, podobne - w akcentowaniu różnicy, co nie oznacza negatywnego waloryzowania powtórzenia ani uznania każdej różnicy za przejaw sztuki.

Powtórzenie w sztuce jest koniecznym warunkiem dojścia do głosu różnicy pojawiającej się $\mathrm{w}$ dyskursie artystycznym w akcie buntu przeciw temu, co powielane i zasiedziałe. W dziejach sztuki ujawnia ono swoją moc jako siła oswajająca opinię publiczną z różnicą (która często w sferze odbioru sztuki wiąże się z szokiem i odrzuceniem), co więcej, z czasem nadaje jej walor 
zasady. Moment ten jest nadaniem różnicy cech prototypu, który inicjuje różne formy powtórzeń - od inspiracji do tworzenia dzieł oryginalnych po zwykłą produkcję. Ta ostatnia, pojawiająca się po wyczerpaniu możliwych wariacji i interpretacji różnicy, staje się dla sztuki nieznośna - przekształca ja bowiem w fabrykę banalnych, przewidywalnych przedmiotów estetycznych, ozdobę miernej jakości, coś, co może odpowiadać na gust powszechny, ale pozbawione zostaje wartości zdarzenia sztuki. To chwila, w której przekroczona zostaje granica sztuki, oddzielająca ją od tego, co sztuką nie jest. Powtarzalność prowadzi kulturę artystyczną do osiagnięcia stanu, który Jean Baudrillard nazywa narzucającą się nadwyżką sztuki i momentem, w którym sztuka umiera ${ }^{1}$. Baudrillard odnosi te słowa do współczesnych produkcji inspirowanych sztuką ready-made, twórczością Duchampa, których konsekwencją stało się, według myśliciela, transestetyzowanie wszystkiego i pogrążanie się sztuki w banale ${ }^{2}$. Wydaje się jednak, że zasada ta równie dobrze odnosi się do dziejów sztuki, w której pojawiające się arcydzieła, nie zawsze na początku akceptowane, stawały się szybko inspiracją dla przetworzeń i wariacji, tworzyły szkoły, by następnie paść łupem taniego naśladownictwa. Użycia różnicy wpisują w nią zatem jakiś rodzaj powtarzalności, „[...] za każdym razem, - pisze Deleuze - gdy natrafimy na jakiś wariant, różnicę, przebranie, przemieszczenie, powiemy, że chodzi o powtórzenie, ale tylko w sposób pochodny i przez «analogię»" Nieusuwalność związku różnicy i powtórzenia w przestrzeni sztuki leży u podstaw wyznaczającego ontyczność sztuki nieustannego rozmywania, przekraczania i przesuwania ustanowionych granic.

Kultura, a zatem i sztuka rozwijają się w procesie nieustannych przekształceń. Adaptacja, przekład (językowy, semiotyczny, medialny), parafraza, użycie, recykling są narzędziami przekraczania granic w sztuce. Nazywają też formy działania w kulturze, które określić można wspólnym mianem przetworzenia, będącego jednym z podstawowych zabiegów tekstotwórczych, zasadą sztuki i ważnym procesem kulturowym.

Akt przekształcenia, zakotwiczony zarówno w różnicy i zmianie przedmiotu przekształcenia, jak i w powtórzeniu (zawartym w obecności tego, co zmieniane), jest momentem, w którym różnica i powtórzenie ujawniają

${ }^{1}$ J. Baudrillard, Spisek sztuki. Iluzje i deziluzje estetyczne $z$ dodatkiem wywiadów o Spisku sztuki, przeł. S. Królak, Warszawa 2006, s. 109.

${ }^{2}$ Tamże, s.106.

${ }^{3}$ G. Deleuze, Różnica i powtórzenie, przeł. B. Banasiak, K. Matuszewski, Warszawa 1997, s. 372. 
swoje uczestnictwo w dzianiu się sztuki. Powtórzenie gwarantuje ciagłość sztuki, która swoje istnienie i odnawianie lokuje w kolejnych różnicach. Jest wehikułem transportującym ją bezpiecznie od jednej różnicy do kolejnej, której pojawienie się i wygasanie jednocześnie powoduje. Z kolei różnica, jako siła napędowa przetworzenia w sztuce, uniemożliwia przekroczenie granicy, poza którą sztuki już nie ma, pozwala więc na ciagłe jej odnawianie się, czyniące ją bytem bez granic.

Przetworzenie jest przekształceniem jakiegoś elementu (A), w wyniku czego powstaje inny element (A' lub B). Może być działaniem na danym przedmiocie - wówczas go odkształca, sprawia, że zyskuje on nową postać (A') lub może prowadzić do powstania nowego przedmiotu (B) z zachowaniem tego, który stanowił inspirację do działania przekształcającego. W pierwszym przypadku rzecz przekształcona nosi w sobie pamięć tego, co poprzednie, przy czym pamięci nie należy utożsamiać z rozpoznawalnymi dla odbiorcy śladami. Możliwe są zatem sytuacje, gdy przedmiot przetworzony ma wyraźne oznaki przekształcenia (tak jest w architekturze - przebudowywaniu czy rozbudowie konstrukcji architektonicznych zgodnie z nowym stylem), sytuacje, gdy ślady te zostają ukryte pod powierzchnią (przykład palimpsestów w sztukach ikonicznych), ale też przypadki, gdy ślady przetworzenia zostają zatarte. W przypadku, gdy przekształcenie nie narusza rzeczy przekształcanej w jej materialnym istnieniu, ale odnosi się do semiosfery, tematu, stylu, formy tekstowej, ustanawiając nowy sposób ich istnienia, lokuje się w pozycji siły reinterpretującej. Powstały w wyniku przetworzenia utwór wchodzi ze swoim hipotekstem w dialog, polemikę, wiąże się z nim, ale też od niego odrywa, ustanawiając własne życie.

Przekształcenie może więc dotyczyć różnych sfer tekstu i mieć różny stopień zaawansowania. Przetworzenie, które jest ruchem od jednego elementu do drugiego, naraża swój efekt na porównywanie, konfrontację z tym, co wyjściowe. W świecie tekstu (utworu artystycznego, który dostał się już w obieg kultury) takie przetworzenie wiąże się z uzyskaniem innego tekstu i jest zdarzeniem intertekstualnym. Tak jest w przypadku adaptacji czy przekładu literatury, gdzie kategoria przetworzenia ma charakter metaforyczny, nie dochodzi bowiem do naruszenia tekstu przetwarzanego. Przykładu takiego naruszenia dostarcza architektura, gdzie adaptacja, przeróbka modyfikują dzieło pierwotne.

Wymienione pojęcia, lokujące się w przestrzeni przetwarzania kultury, moga mieć status narzędzi, a mogą też, w momencie, gdy zyskują pozycję dominująca, organizującą sposób istnienia utworu, stawać się nazwą gatunkowa. Kategorie te bardzo często zazębiają się, wchodzą ze sobą w interakcje, różniąc się między sobą zwykle akcentowaniem jakiejś cechy. I tak, parafraza nazywa tekst, który jest przeróbka, modyfikacją innego

\footnotetext{
211 O twórczym przekraczaniu granic
} 
tekstu - zwykle rozwijająca, prowadząca do zmian w sferze treści, stylu zachowująca jednak rozpoznawalność pierwowzoru. Kładzie nacisk na akt przeróbki, transformacji przy zachowaniu tematu (tak dzieje się w parafrazach literackich, muzycznych, lingwistycznych). Z kolei w przypadku recyklingu, który jest przetwarzaniem tego, co niepotrzebne, zużyte - co stanowi kulturowy odpad, a co dzięki przetworzeniu może wrócić na salony kultury, nacisk kładziony jest na odzyskiwanie, nadawanie drugiego życia temu, co odrzucone, uznane za zbędne, do niczego nieprzydatne. Recykling jest przetwarzaniem rewitalizującym różne teksty, użyciem ich na nowo po przetworzeniu; nie jest wyłącznie ruchem od jednego tekstu do drugiego, ale działaniem, które może odnosić się do różnych tekstów jednocześnie, przekształcać je, łączyć, używać do nowych celów, tworząc nową jakość, niezależną od tekstów poddanych przetworzeniu. Za formę recyklingu przekraczającej granice dyskursywne sztuki uznać można ready-made. Z kolei troska o ekwiwalencję w sferze treści, formy artystycznej, idei charakteryzuje przekład (translację), który jest zawsze ruchem od jednego tekstu - przekładanego - do drugiego - rezultatu przekładu. W przekładzie tekst pierwotny zachowuje swoją niezależność i silną pozycję oryginału. Rezultat przekładu ma być jego odpowiednikiem i jako taki uznawany jest zawsze za wtórny wobec niego, przy czym wtórność nie oznacza bycia gorszym, o czym świadczy kategoria przekładu kongenialnego, nazywająca taki przekład, którego walory artystyczne stawiaja go na równi z pierwowzorem. Tu już zdaje się być niedaleko do takiego przekładu, którego efektem jest uzyskanie tekstu przewyższającego oryginał pod względem formy artystycznej, a zatem do takiego przetworzenia, w którym przekład adaptujący ustępuje miejsca przekładowi artystycznemu ukonstytuowanemu na inspiracji.

W przekładzie przetworzenie może dotyczyć systemu znaków językowych z jednego języka na inny (przekład językowy), z systemu językowego na niejęzykowy lub mieszany i odwrotnie (przekład semiotyczny), z jednego systemu medialnego na inny (przekład medialny). Przekład medialny jest zwykle jednocześnie przekładem semiotycznym, na przykład utwór literacki i filmowy należą zarówno do odmiennych systemów medialnych, jak i korzystaja z odmiennych kodów semiotycznych. Przekraczanie granic systemu językowego, semiotycznego, medialnego, środowiska dyskursywnego rzutuje na sferę znaczeń. Sprawia, że w utworze dokonują się przesunięcia w sferze cech drugorzędnych, które nie powodują utraty przez utwór związku z pierwowzorem, ale nadają mu status utworu osobnego.

Jeszcze inaczej rzecz ma się z adaptacją, która, rozumiana jako przystosowanie, jest kategorią lokująca się ponad granicami praktyk, sztuk, dyskursów i mediów, obecną w najrozmaitszych sferach życia społecznego. Można bowiem adaptować się do nowych warunków życia, zaadaptować 
tekst baśni braci Grimm zawierający drastyczne sceny do potrzeb niedorosłego odbiorcy; tekst oryginału w jednym języku do potrzeb osoby uczącej się danego języka - uprościć składnię, leksykę, warstwę frazeologii; zaadaptować tekst literacki do potrzeb filmu, teatru. W procesie przystosowywania modyfikacji ulega nie tylko system medialny i semiotyczny, ale także zostaje nią objęta przestrzeń fabuły - zmiany mogą dotyczyć wszystkich typów wątków, postaci, zdarzeń, a nawet idei utworu. Adaptacja filmowa utworu literackiego, komiksu, narracyjnej gry wideo jest więc przekładem semiotycznym i medialnym, ale także parafraza, a przede wszystkim interpretacją tekstu wyjśsiowego.

Warto tu podkreślić, że adaptacja jako jedyna spośród wymienionych wyżej form przetworzenia zyskała cechy nazwy gatunkowej. Chodzi mianowicie o adaptację filmową utworów literackich. Kategoria ta stała się odpowiedzią na klasyfikację filmów z uwagi na podstawę tworzenia i służyła odróżnieniu filmów kręconych na podstawie utworów literackich od tych, które powstawały na bazie oryginalnych scenariuszy. Kariera, jaką pojęcie adaptacji zrobiło w przestrzeni filmu fabularnego (stając się nazwą typologiczna), a w konsekwencji w filmoznawstwie ${ }^{4}$, wynikała z faktu, że gatunek ten niemal od początku stanowił dominantę kinematografii i od początku czerpał pomysły fabuł z literackich (zwłaszcza fikcjonalnych) gatunków narracyjnych.

Adaptacja filmowa jest mniej lub bardziej dokładna transpozycją elementów fabuły utworu literackiego (obecnie też komiksowego, growego) w nowe środowisko medialne, a tym samym semiotyczne i komunikacyjne. Transpozycja (tematu, fabuły i jej elementów) charakteryzuje się znaczną rozciagłościa - od możliwie maksymalnego naśladowania pierwowzoru w sferze wymowy ideowej, akcji, wątków, postaci, zdarzeń do mniej lub bardziej daleko idących modyfikacji. Wydaje się, że o adaptacji można mówić tak długo, jak długo w danym utworze odbiorca rozpoznaje przedmiot adaptacji (czyli elementy fabuły i związki między nimi). Dlatego włączenie do adaptacji takich kategorii jak inspiracja, użycie są sporne. Traktowanie ich jako mieszczących się w ramach tej formy przetworzenia jest sprawą uznaniową i zależy od konkretnej realizacji. Podobnie, jeśli widz nie rozpozna

${ }^{4}$ By przywołać np. A. Bazin, O film nieczysty-obrona adaptacji filmowej, [w:] Film i rzeczywistość, wybór tekstów, przeł. B. Michałek, Warszawa 1963, s.79-103; M. Choczaj, O adaptacji, ekranizacji, przektadzie intersemiotycznym i innych zmartwieniach teorii literatury, filmu i mediów, „Przestrzenie Teorii” 2011, nr 16; A. Helman, Adaptacja-podstawowa technika twórcza kina, [w:] Intermedialność w kulturze końca XX wieku, red. A. Gwóźdź, S. Krzemień-Ojak, Białystok 1998; M. Hopfinger, Adaptacje filmowe utworów literackich. Problemy teorii i interpretacji, Wrocław 1974; A. Jackiewicz, Film jako powieść XX wieku, Warszawa 1968; T. Miczka, Adaptacja, [w:] Stownik pojęć filmowych, red. A. Helman, t. 10, Kraków 1998; M.W. Osadnik, Adaptacja filmowa jako przekład, [w:] Kino wedtug Alicji, red. W. Gwóźdź, T. Lubelski, Kraków 1995; G. Wagner, The Novel and the Cinema, Rutherford-New York 1975. 
przedmiotu adaptacji, na przykład dlatego, że go nie zna, utwór nie będzie dla niego adaptacją $\mathrm{w}$ procesie odbioru. $\mathrm{W}$ takiej sytuacji można mówić o braku odbiorczego doświadczenia adaptacji, choć widz może przyjać do wiadomości i zaakceptować informację, że ma do czynienia z przetworzeniem.

Adaptacja filmowa związana jest zarówno z transpozycją elementów tematycznych, jak i zmianą w sferze semiotyki tekstu, medium oraz dyskursu, jaki nowy tekst reprezentuje. Zmiana środowiska znakowego, medialnego i dyskursywnego powoduje też przesunięcia w sferze struktury tekstu artystycznego, prowadząc do przesuwania granic poetyki.

Sztuka opiera się na nieustannych inspiracjach, użyciach przekształcających, wręcz deformujących to, co zastane. Adaptacja w świecie sztuki jest twórczą interpretacja - często autointerpretacja, która nie może być egzegeza, gdyż nie chodzi tu o wyjaśnienie ukierunkowane na przedmiot wyjściowy, nie chodzi o zwrot ku temu przedmiotowi, ale o działanie przeciwne - zwrot ku temu, co nowe i to niezależnie od tego, czy przedmiotem adaptacji jest sztuka czy jest nim niesztuka. Chodzi o użycie ${ }^{5}$, różniące się od użyć spoza kręgu sztuki ukierunkowaniem estetycznym. Podczas zatem, gdy w innych dziedzinach takie interpretacje pełnia funkcję poznawcza (nauka), perswazyjna (polityka, reklama), informacyjną (dyskurs dziennikarski), w przestrzeni artystycznej uczestniczą w kształtowaniu doświadczenia estetycznego.

W sztuce nie ma granic przekształcania. Przedmiotem adaptacji moga być zarówno utwory artystyczne - dawne (adaptacja diachroniczna) i współczesne (adaptacja synchroniczna), jak i pochodzące spoza kręgu sztuki. Podstawową zasadą działania adaptacyjnego jest ukierunkowanie na działanie twórcze - adaptacja jest twórczą zmiana, którą Alicja Helman przed laty przewrotnie nazwała twórcza zdrada ${ }^{6}$. Jako twórcza zmiana adaptacja dowodzi wierności istocie sztuki ukierunkowanej na kreację estetyczną. Jest forma dialogu artystycznego z pretekstem, odpowiedzią na tekst, który ja inspiruje. Będąc formą interpretacji realizowanej w przestrzeni sztuki, jest uznaniem dla tekstu pierwotnego, przedłużeniem pamięci o nim. Dzięki adaptacji pretekst zyskuje nowe życie, odradza się; ujawnia swą moc inspirowania do działań twórczych - do inicjowania nowych tekstów, przekraczania własnych granic. Jako taka adaptacja wpisuje się w projekty zapowiadające koncepcję rozprzestrzenialnych mediów ${ }^{7}$.

${ }^{5} \mathrm{O}$ użyciu w kontekście innych form interpretacji zob. np. M.P. Markowski, Interpretacja i literatura, „Teksty Drugie” 2001, nr 5, s. 50-66; U. Eco, Lector in fabula. Współdziałanie w interpretacji tekstów narracyjnych, przeł. P. Salwa, Warszawa 1994, s. 261.

${ }^{6}$ A. Helman, Twórcza zdrada. Filmowe adaptacje literatury, Poznań 1998.

${ }^{7}$ Zob. H. Jenkins, S. Ford, J. Green, Rozprzestrzenialne media. Jak powstaja wartości i znaczenia w usieciowionej kulturze, przeł. M. Wróblewski, Łódź 2018. 
W procesie adaptacji interpretowanie jest tworzeniem filmowej reprezentacji własnego rozumienia danego utworu, co w sposób konieczny oznacza jego przeróbkę. Akt przetworzenia wiąże element powstały z pierwotnym, z tym, do którego się odnosi. Aby ów związek był rozpoznawalny, potrzebne sa odniesienia do pretekstu - zarówno tematyczne, jak i formalne - potrzebne są aluzje, cytaty.

Szczególnie ciekawy wydaje się status i charakter odesłań, które decydują o rozpoznawalności adaptacji, a które wahają się między quasi-cytowaniem, parafrazą a reprezentacja. Na marginesie pozostawiam tu formuły paratekstowe takie jak: na podstawie..., adaptacja..., na motywach... Oczywiście nie każdy akt przywołania, zwłaszcza jednostkowy, decyduje o tym, że mamy do czynienia $\mathrm{z}$ adaptacja. Wręcz przeciwnie, potrzebna jest wiązka elementów oraz relacji między nimi. W procesie adaptacji elementy danego utworu ulegają przekształceniu, poczynając od modyfikacji, jakich dokonują $\mathrm{w}$ nich zmiana systemu semiotycznego i medium (literatura-teatr, literatura-film), przez zmiany stylistyczne (na przykład uproszczenia, zmiany związane z ukierunkowaniem na określonego odbiorcę), tematyczne (transpozycje), a kończąc na zamiarze twórczym adaptatora. Przekraczają granice swego tekstu, by w przekształconej formie zaistnieć w nowym tekście.

W przypadku utworów fabularnych momentami identyfikujacymi adaptację są kluczowe wątki związane z głównymi postaciami, ale też same te postaci, których wygląd, temperament, charakter powinny nie tyle pokrywać się z wyobrażeniami o nich widzów jako czytelników pierwowzoru, co raczej charakteryzować się zdolnością do wyparcia i zastapienia wyobrażeń czytelniczych widza, a przynajmniej do bycia zaakceptowanymi przez niego.

Formą przekształcenia, która charakteryzuje się znaczną uniwersalnościa, jest przekład intersemiotyczny. Kategorię tę już w latach siedemdziesiątych stosowała Maryla Hopfinger ${ }^{8}$, nazywając nią adaptacje filmowe dzieł literackich i wyodrębniając nieprzekładalne, przekładalne i częściowo przekładalne poziomy tekstu w przekładzie z jednego systemu znaków na inny. Kategorią tą posługuje się też Marek Hendrykowski w odniesieniu do adaptacji filmowej, wzbogacając ją o kategorię przekładu intermedialnego. Badacz analizuje siedem podstawowych operacji adaptatorskich: substytucję, redukcję, addycję, amplifikację, inwersję, transakcentację oraz kompresję . O czterech podstawowych operacjach retorycznych (amplifikacji, redukcji, immutacji oraz substytucji), jako tych, którym podlega przekład intersemiotyczny, pisała wcześniej Seweryna Wysłouch. Według niej operacje

${ }^{8}$ M. Hopfinger, dz. cyt.

${ }^{9}$ M. Hendrykowski, Adaptacja jako przektad intersemiotyczny, „Przestrzenie Teorii” 2013, nr 20, s. 179-183. 
te stosują się do każdego przekładu. Opisane przez Edwarda Balcerzana jako kategorie retoryczne, sa - jak pisze Wysłouch, odwołując się do prac Jerzego Ziomka - „niezdeterminowane substancją tekstu i działające na ponadjęzykowym poziomie znaczeniowym" ${ }^{10}$. To sprawia, że sprawdzaja się w analizie przekazów wieloznakowych. Opowiadając się za kategorią przekładu intersemiotycznego, badaczka uznaje ją za w znacznym stopniu uniwersalna. Według niej kategoria ta

obejmuje nie tylko teksty pisane, ale najróżniejsze adaptacje - radiowe, teatralne, filmowe. W przeciwieństwie do ekfrazy, skierowanej na naśladowanie wzorca, koncentruje uwagę na procesach, które wzorzec modyfikuja, jak konceptualizacja i symbolizacja. Zwraca uwagę na relacje intertekstualne i przemieszczenia w polisystemie kultury ${ }^{11}$.

Zgadzając się z ustaleniami dotyczącymi kategorii przekładu intersemiotycznego, muszę wyrazić swoją wątpliwość dotyczącą stosowności użycia $\mathrm{w}$ jej nazwie przedrostka inter-. Za uzasadnione uważam mówienie o intersemiotyczności w celu nazwania tym pojęciem relacji między systemami semiotycznymi czy tekstami, które reprezentują różne systemy znakowe. Mniej przekonujące, bo redundantne wydaje mi się natomiast mówienie o przekładzie intersemiotycznym. Przekład zakłada działanie między systemami; jest ujęciem w jednym systemie treści utrwalonych w innym. Uważam zatem za całkowicie wystarczające mówienie o przekładzie semiotycznym czy medialnym, tak samo zresztą jak wystarczające okazało się mówienie o przekładzie językowym (nie ma kategorii przekładu interjęzykowego).

Wymienione dotychczas pojęcia łączy to, że nazywają formy przetworzeń. Inaczej jest z reprezentacją, nieutrzymująca związku z jednym utworem bądź wieloma utworami, których byłaby bezpośrednim przekształceniem, ale lokująca się w pozycji działania czy występowania w imieniu czegoś. Reprezentować to być wyrazicielem, przedstawicielem czegoś. To użyczać siebie na potrzeby czegoś innego, załatwienia jakiejś sprawy. Reprezentacja oparta jest na myśleniu synekdochalnym. Może stać się impulsem do tworzenia przez odbiorcę wyobrażenia przedmiotu odniesienia, ale jest wobec niego czymś osobnym. W świecie tekstu artystycznego reprezentacja odsyła zwykle do tego, co ogólne czy uniwersalne - na przykład zasady, idei, formy, motywu, postawy. Dany utwór literacki reprezentuje zatem konkretny gatunek, bohater literacki czy filmowy - typ postawy ludzkiej, twórczość malarza i jego dzieło -

${ }^{10} \mathrm{~S}$. Wysłouch, Ekfraza czy przektad intersemiotyczny, [w:] Ruchome granice literatu$r y$, red. S. Wysłouch, B. Przymuszała, Warszawa 2009, s. 57. Zob. też przywoływane przez badaczkę E. Balcerzan, Poetyka przekładu artystycznego, [w:] tegoż, Oprócz głosu. Szkice krytycznoliterackie, Warszawa 1971; J. Ziomek, O wspótczesności retoryki, [w:] tegoż, Prace ostatnie, Warszawa 1994, s. 144.

${ }^{11}$ S. Wysłouch, Ekfraza czy przekład intersemiotyczny..., s. 64. 
określony nurt w malarstwie. Reprezentacja byłaby zatem ucieleśnieniem czy konkretyzacja jakiejś idei, zasady. Ta jej cecha naraża ją w świecie sztuki na powtarzalność, nudę, brak oryginalności, obiecując w najlepszym wypadku doskonałe rzemiosło. Tymczasem istota sztuki jest brak pokory wobec zastanych norm, wręcz niesforność, która jest podstawą oryginalnych kreacji, warunkiem narodzin arcydzieła. To sprawia, że w świecie sztuki ograniczenia reprezentacji są przełamywane na drodze wprowadzenia elementu wariacji, polemiki, reinterpretacji zasady czy idei, do której utwór się odwołuje. Tak było w przypadku Lalki Bolesława Prusa, która okazała się niepokorna wobec idei powieści realistycznej, Śniadania na trawie czy Olimpii Édouarda Maneta, które łamały współczesne sobie zasady przedstawienia, wywołując skandal. Utwory tego typu z jednej strony deklarują bycie reprezentacją określonego gatunku, typu przedstawienia, z drugiej zaś w konkretnej realizacji polemizują z nimi, rozsadzając ramy ścisłej reprezentacji.

Reprezentacja w sferze sztuki może wykraczać poza granice własnego dyskursu i wkraczać w przestrzeń innych dyskursów. Ciekawego przykładu dostarcza tu Pietà Michała Anioła. Wizerunek Matki Bożej trzymającej na kolanach martwe ciało zdjętego z krzyża Syna interpretować można jako artystyczną reprezentację - syntezę dogmatu konstytuującego dyskurs jednej z największych religii (chrześcijaństwa). Oto bowiem twarz wyrzeźbionej kobiety i jej postać sa przedstawieniem młodej dziewczyny, gdy tymczasem wygląd spoczywającego na kolanach mężczyzny wskazuje na człowieka dorosłego (ewangelie określają ten wiek na około 33 lata). Nie jest zatem możliwe, by przedstawienie Michała Anioła odnosiło się do realnej, biologicznej relacji między Matką Bożą i Synem. Rzeźba jest raczej reprezentacja symbolicznej syntezy kluczowych dla dogmatu momentów prezentowanych w narracji nowotestamentowej jako oddalone od siebie w czasie, tu zaś ujętej w formie czasoprzestrzennej hybrydy różnych zdarzeń. Sa to narodziny powiązane ze zwiastowaniem oraz śmierć, po której następuje zmartwychwstanie. Znakiem pierwszego z nich są: dziewczęca twarz, która kojarzy się bardziej z Maryją Panną (i Madonna) niż z bolejąca matka, ale też wyraz twarzy Maryi, pochylenie głowy i otwarta dłoń, które wyrażają przyjęcie ze spokojem i akceptacją woli Boga, wreszcie wysunięte ku przodowi biodra i rozchylone kolana ukryte pod bogatym marszczeniem tkaniny, które przywołuja akt rodzenia. Znakiem drugiego momentu jest akt podtrzymywania ciała Chrystusa, ale też otwarta dłoń akceptująca wolę Boga oraz wspomniana postawa ciała nawiązująca za pośrednictwem znaku narodzin do odrodzenia w zmartwychwstaniu. Dzieło Michała Anioła łączy w sobie przekraczanie granic życia i śmierci, życia biologicznego i metafizyki, tego, co ludzkie i tego, co Boskie, wreszcie cierpienia matki rodzącej i matki doświadczającej śmierci własnego dziecka. 
Zaproponowana tu interpretacja rzeźby jako artystycznej reprezentacji dyskursu religijnego powiązanego z ludzkim doświadczeniem i artystycznej syntezy kluczowych dla chrześcijaństwa momentów odsłania zdolność sztuki do przekraczania granic zewnętrznych - wkraczania w sferę innych dyskursów, praktyk - wręcz kolonizowania ich.

Ciekawego przykładu reprezentacji polemicznej - rozsadzającej z kolei granice wewnętrzne sztuki - w tym przypadku formy plastycznej, jaką jest Pietà, dostarczają rzeźba cyfrowa: The inevitability of time/Pietà Adama Martinakisa (il. 1) ${ }^{12}$ oraz wiersz Pietà Wisławy Szymborskiej. Tytuły obu utworów zapowiadają reprezentację tematu ujętego w dziele Michała Anioła, ale też w wielu innych przedstawieniach ikonograficznych, literackich czy teatralnych ujmujących motyw matki bolejącej nad złożonym na jej kolanach ciałem Chrystusa. Jednak zarówno w jednym, jak i drugim utworze czynnik religijny schodzi na plan dalszy. Utwór Szymborskiej ukazuje matkę po stracie syna, rzeźba Martinakisa jest przedstawieniem cierpienia i błagania kobiety trzymającej rozpadające się ciało mężczyzny. Oba utwory bardziej niż do tradycji religijnej odwołują się do włoskiego słowa „pieta” nazywającego litość, miłosierdzie.

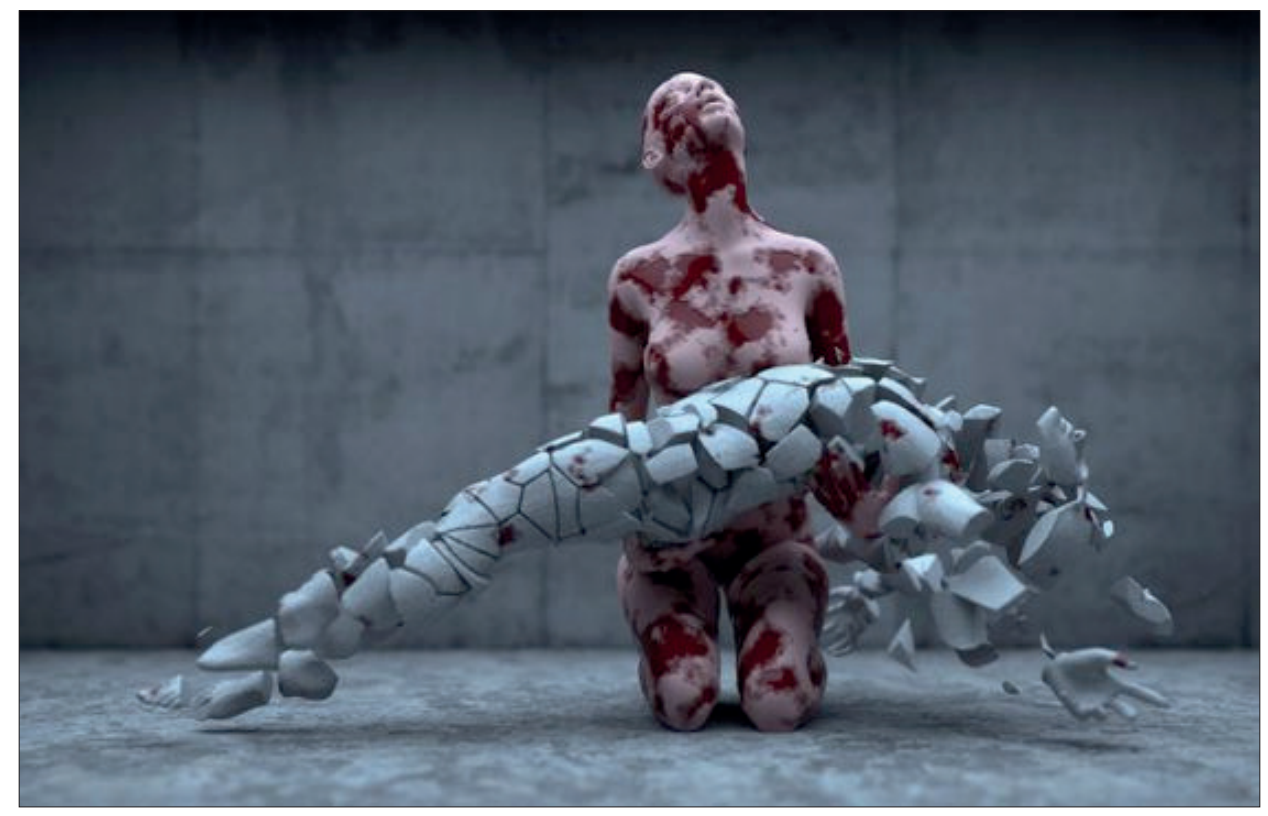

Ryc. 1. Adam Martinakis, The inevitability of time /Pietà (2013)

${ }^{12}$ Adam Martinakis, The inevitability of time/Pietà, 2013, <http://niezlasztuka.net/ portfolio/adam-martinakis/> [dostęp: 14.11.2018]. 
W przypadku The inevitability of time/Pietà Martinakisa odejście od jednostkowego, konkretnego przypadku dokonuje się za sprawą uniwersalizacji elementów przedstawienia. Utwór prowadzi grę z odbiorca. Oto z jednej strony przedstawione postaci mogą być każdym człowiekiem - kobieta i mężczyzna, z drugiej jednak kształt całości nieuchronnie przywodzi na myśl tradycję przedstawień religijnych, a za ich pośrednictwem odsyła do dogmatu. W postawie kobiety dostrzec można cierpienie, skargę i błaganie. Różowa barwa jej ciała konotuje życie, ale i traumę, fizycznie odczuwany ból, których znakiem sa krwawe plamy widoczne na całym ciele. Kontrastuje z zimnym, szaroniebieskim, sztywnym ciałem mężczyzny, które niejako rozpada się na oczach odbiorcy, konotując śmierć, przemijanie. Rozpadanie się ciała na fragmenty demaskuje jego niebiologiczną materię. Odsłania fikcjonalny charakter przedstawienia, to, że widz ma do czynienia z rzeźba, z potłuczonym, rozbitym na kawałki gipsowym posagiem. Pęknięcia, kawałki posagu przywodzą na myśl materię rzeźby, a przecież utwór cyfrowy jej nie ma. Kolejna gra z odbiorca polega na wytworzeniu w nim poczucia obcowania z fizykalną materią rzeźby, jest grą w fikcję. Utwór Martinakisa nawiązuje do tradycji rzeźby a jednocześnie manifestuje jej przekraczanie, czyniąc tematem moment, w którym następuje rozpad. To, co niemożliwe do przedstawienia dla rzeźby materialnej - unieruchomienie dynamiki rozpadu, tu uzyskuje swą pełnię. Paradoks polega na tym, że niematerialna w swej istocie i łatwo poddająca się przeróbce rzeźba cyfrowa utrwala, utrzymuje w całości akt rozpadu.

Utwór jest syntezą tego, co biologiczne (barwa ciała kobiety) i niebiologiczne (pokawałkowane, szare ciało mężczyzny) - życia i sztuki. Do tego można całość interpretować jako polemikę z tradycją piety, sięgającą początków XIV wieku. Ujęta w tytule nieubłagalność czy nieuchronność czasu, który skazuje nas na przemijanie, może też odnosić się do uprawianych form i tematów plastycznych (takich jak pietà), do samej sztuki rzeźbiarskiej, której materia, techniki, podejmowane tematy zmieniają się z czasem, rozpadają na kawałki, podobnie jak trzymane przez kobietę ciało. W kategoriach przemodelowania, rozpadu mogą też być rozpatrywane dzieje dogmatu religijnego, do którego odwołuje się pietà. Odbiorca ma tu zatem do czynienia z hybryda kilku reprezentacji - z forma, która rozsadza własne granice. Dzieje się tak dlatego, że reprezentowanie motywu zostaje zespolone z byciem wyrazicielem idei sztuki, która jest twórcze przetwarzanie.

O reinterpretacji przedmiotu reprezentacji można też mówić w przypadku wiersza Szymborskiej. Tu również rezygnuje się z motywu biblijnego. Zamiast Matki Bożej pojawia się zwykła kobieta - matka zabitego syna. Reprezentacja literacka piety ożywia przedstawienie i lokuje je w wyobraźni czytelnika. Co więcej, zastępuje je serią zdarzeń. Pietà Szymborskiej to wi- 
zerunek matki, której syn był więziony i został rozstrzelany, domyślamy się, że za dążenia wolnościowe, skoro nazwano go bohaterem, stworzono w miasteczku muzeum i wystawiono pomnik, będący główną atrakcją turystyczna. Atrakcją turystyczna jest też matka bohatera, która publiczne wywiady, wystapienia pozbawiaja prywatności i autentyczności. Obcość, dystans i sztuczność relacji podkreślone zostają nagromadzeniem bezokoliczników oraz posłużeniem się mową pozornie zależna. Litość, miłosierdzie - treści, które niesie słowo pietà - w przypadku turystów odwiedzających kobietę zostają zastapione ciekawością. Z kolei w procesie odbioru utworu większą litość (niż tłumione cierpienie kobiety) może wywoływać przekształcenie jej osobistego doświadczenia w medialną i turystyczną atrakcję. Utwór Szymborskiej jest w rezultacie reprezentacją przetwarzająca zarówno temat, jak i ideę typowej piety. Wreszcie, co bardzo istotne, staje się literacką reprezentacją rzeźby. Nagromadzenie form bezosobowych, paralelizmów składniowych, w które wpisane zostają automatyczne, rutynowe odpowiedzi kobiety; mechaniczne, powtarzane, pozbawione emocji zachowania turystów sprawiaja, że cierpienie kobiety i jej świadectwo odarte zostają z tego, co osobiste, ludzkie. Pozbawione życia, nabieraja cech posagu - nieruchomej, materialnej rzeźby.

Sztuka zatem nieustannie przekracza zarówno własne granice zewnętrzne, konfrontując się z innymi dyskursami, jak i wewnętrzne - konfrontując formy sztuki różniące się między sobą materią i systemami semiotycznymi. Jest to możliwe dzięki strukturalnej wspólnocie sztuk ${ }^{13}$ opierającej się, jak pisze Wysłouch ${ }^{14}$ na istnieniu ponaddziedzinowych struktur, operacji tekstotwórczych $^{15}$. Takimi strukturami sa np. figury, kompozycja, narracja. Kategorią umożliwiającą wzajemne przenikanie się sztuk jest też (obecny w badaniach Uspienskiego) punkt widzenia ${ }^{16}$.

Ciekawego przykładu konfrontowania i jednocześnie uzupełniania się wzajemnie punktów widzenia: zewnętrznego i wewnętrznego dostarczają

${ }^{13}$ Zob. B. Uspienski, Strukturalna wspólnota różnych sztuk. Ogólne zasady organizacji dzieła malarskiego i literackiego, przeł. P. Fast [w:] tegoż, Poetyka kompozycji. Struktura tekstu artystycznego i typologia form kompozycji, Katowice 1997, s. 191-244.

${ }^{14}$ S. Wysłouch, Literatura i obraz. Tereny strukturalnej wspólnoty sztuk, [w:] Intersemiotyczność. Literatura wobec innych sztuk (i odwrotnie), red. S. Balbus, A. Hejmej, J. Niedźwiedź, Kraków 2004.

${ }^{15}$ Wysłouch i Uspienski piszą o strukturalnej wspólnocie sztuk, ale wskazywane przez nich operacje tekstowe są realizowanymi w przestrzeni sztuki strukturami myślenia, które znajdują swe tekstowe konkretyzacje również w innych dyskursach. To sprawia, że możliwe jest przekraczanie granic sztuki w stronę innych dyskursów (nieartystycznych), możliwy tė̇ jest opis poetyki innych dyskursów (jak choćby reklamy, zob. E. Szczęsna, Poetyka reklamy, Warszawa 2001, 2003).

${ }^{16}$ B. Uspienski, dz. cyt. 
Upadek ślepców Gerta Hofmanna i Ślepcy Pietera Bruegla. Zewnętrzny punkt widzenia - dominujaccy w obrazie, reprezentowany jest przez osoby widzące (świadka - odbiorcę obrazu, twórcę-malarza), ale i sztukę malarska, dla której wzrok jest najważniejszym zmysłem. Zostaje on skonfrontowany $\mathrm{z}$ dominująca $\mathrm{w}$ powieści perspektywą wewnętrzną reprezentowaną przez bohaterów tytułowych, ale też doświadczeniem, jakie dostępne jest osobie niewidzącej oraz sztuce słowa - bardziej niż malarstwo predysponowanej do odzwierciedlania myśli, odczuć, doznań czy biegu zdarzeń. Utwory zestawiają opozycje: zewnętrzne a wewnętrzne, widziane a odczuwane, doświadczane wzrokiem a doświadczane innymi zmysłami, narratywizowane a opowiedziane, by następnie uczynić je częścią jedności - dyskursu sztuki. Mamy więc do czynienia z konfrontacją uzupełniających się w istocie perspektyw poznawczych - widzenia zewnętrznego (oka świadka - widza czy malarza) i wewnętrznego (oka bohatera); ale też z konfrontacją różnych dyskursów, dla których wspólnym punktem odniesienia sa ślepcy.

Oba utwory odkrywaja odmienne perspektywy poznania, lub raczej utwór Hofmanna tworzy impuls do spojrzenia na obraz Bruegla jako reprezentację zewnętrznego punktu widzenia kreowanego przez zmysł wzroku. Dominanta jest to, co reprezentatywne dla malarstwa - tworzenie przedstawienia dla oka zewnętrznego. Przedmiot przedstawienia, temat zdają się blokować inną interpretację - to, co ukazane na obrazie, nie może być perspektywa widzenia tych, którzy pozbawieni sa wzroku. Widzenie zewnętrzne buduje też reprezentację ikoniczną innych zmysłów: dotyku, słuchu, węchu - ślepcy dotykają się nawzajem, opierają się o siebie, trzymają kije; wysuwaja twarze tak, jak gdyby nasłuchiwali - ich twarze wyrażaja reakcję na dźwięki, zapach, dotyk powietrza. Pełne doświadczenie ich odbioru świata nie jest jednak możliwe dla oka zewnętrznego. Widzenie zewnętrzne rejestruje tylko ikoniczne ślady tego poznania.

Inaczej jest w przypadku powieści Hofmanna, która operuje perspektywą wewnętrzną utożsamianą z doświadczaniem świata przez ślepców. Narracyjne „my” sprawia, że bohaterowie powieści mówią niejako jednym głosem, staja się zbiorową figura narracyjna tak, jak jednością ikoniczna sa ślepcy Bruegla.

Utwór Hofmanna posługuje się punktem widzenia niedostępnym dla przedstawienia Bruegla - percepcją ślepców, ich sposobem odbioru świata. Ślepcy poznają świat dotykiem, powonieniem, tworzą wyobrażenie przestrzeni na podstawie dochodzacych dźwięków, odczuwanej temperatury i wilgotności powietrza, siły wiatru, ale też cudzych wypowiedzi, zasłyszanych rozmów. Obraz rzeczywistości, jaki kreują i jaki staje się też udziałem czytelnika, który ma dostęp tylko do ich perspektywy, jest więc niepewny - stąd w narracji często pojawiają się takie słowa jak: prawdopodobnie, chyba, być może. 
Wchodzenie w dialog intertekstualny tekstów reprezentujących różne sztuki, systemy semiotyczne i medialne sprzyja tworzeniu makrotekstów ${ }^{17}$ utworów nadrzędnych kreowanych w interakcji tekstów różnych autorów, powstałych w różnym czasie, przestrzeni, reprezentujących różne formy sztuki. Takim makrotekstem (czy transtekstem) jest relacja znaczeniowa, w jaką wchodzą obraz Bruegla i powieść Hofmanna. To, co niedostępne widzeniu w przypadku utworu Bruegla, staje się dostępne w doświadczeniu innych zmysłów, których reprezentację tworzy narracja powieściowa Hofmanna.

Utwory różnych sztuk dostarczają zresztą wielu przykładów próby przekraczania własnych granic - sa to próby, gdyż wyjście z danej sztuki blokowane jest przez materię. Chodzi zatem o tworzenie reprezentacji innych sztuk, o wyrażanie w danej sztuce - czynienie jej tematem tego, co stanowi o istocie innej sztuki. Tak jest na przykład w Fotografii Sławomira Mrożka-opowiadaniu, którego pomysł oparty jest na oddaniu fabuła (sposobem prowadzenia narracji) charakterystycznego dla fotografii unieruchomienia zapisu chwili. Tak jest w Hanemannie Stefana Chwina, gdzie w rozdziale "Okno" opis kształtowany jest na kształt pociagnięć pędzla (bohater-narrator buduje obraz ukochanej osoby tak, jak gdyby ją malował - posługując się równoważnikami zdań, konstrukcjami rzeczownikowo-przymiotnikowymi oddającymi kształty, światłocień, barwy). Tak jest w filmie Zacka Snydera 300, Sin City. Miasto grzechu Roberta Rodrigueza, których kadry, ale i montaż oddają specyfikę języka komiksu, Dziewczynie z perta Petera Webbera, Mtynie i krzyżu Lecha Majewskiego czy Duchach Goi Miloša Formana, gdzie kadry filmowe są reprezentacją stylistyki malarskiej odpowiednio: Vermeera, Bruegla, Goi.

Granica wyznaczana przez materię sztuk znika w sztuce cyfrowej, gdzie dwudziestowieczny kolaż i montaż ustępują miejsca hybrydzie i recyklingowi form gatunkowych i dyskursów. Mniej chodzi już o zestawianie elementów do siebie niepasujacych, może nawet przypadkowych, mających różna materię, o łączenie, sklejanie istniejących całostek czy wycinków, bardziej zaś o traktowanie tego, co zastane jako zbioru elementów, które mogą być swobodnie przetwarzane i które moga stać się materią do obróbki w celu uzyskania nowej jakości. Ruch twórczego przetworzenia dokonuje się między dyskursami, sztukami, mediami a uzgodnienie możliwe jest dzięki cyfrowej remediacji. W akcie reinterpretacji w interakcję z literatura coraz częściej wchodzi dyskurs gry. Przykładu dostarcza tu utrzymany w konwencji gry paragrafowej Popiót i diament Agnieszki Słodownik, Michała Danielewicza i Michała Szoty. Utwór wykorzystuje elementy fabuły powieści Jerze-

${ }^{17}$ O makrotekstach zob. E. Szczęsna, Cyfrowa semiopoetyka, Warszawa 2018, s. 365-367. 
go Andrzejewskiego, ale też struktury powieści książkowej (obecny w niej typowy graficzny zapis narracji czy dialogu) oraz struktury gry i powieści hipertekstowej (linki, leksje). Wybór linków sprawia, że użytkownik doświadcza zdarzeń fabuły w określonym porządku - montuje ją z wybieranych leksji, wiąże za pomoca narracji interpretacyjnej. Jednocześnie fakt obecności wielu możliwych porządków organizacji fabuły sprawia, że utwór wielokrotnie czytany w odmiennych porządkach oparty zostaje na narracji alternatywnej ${ }^{18}$. Ruch przesuwania się obrazu po płaszczyźnie, na której widnieją liczne leksje, ruch zbliżania się do tej, która wywołuje akt wyboru jednego z dwóch zaproponowanych linków w oczekiwaniu odbiorczym ciągu dalszego zdarzeń, ruch oddalania się od przeczytanej leksji po kliknięciu na wybrany link zapowiadający ciag dalszy odsłaniaja symultaniczny układ całości - równoważność wszystkich fragmentów współbytujących na płaszczyźnie, gotowych do współtworzenia akcji w momencie, gdy zostaną wywołane przez użytkownika. Ruch ten to cyfrowa remediacja ruchu kamery (jazdy kamery) i ruchu obiektywu (fokus). Remediacja włącza też do utworu sztukę fotografii - chwilę po najeździe na fragment tekstowy - słowny w tle warstwy słownej pojawia się zarys obrazu fotograficznego, który to obraz na prawach kontekstu (tła) uczestniczy w kreowaniu znaczeń utworu. Popiót $i$ diament trojga autorów jest typowym przykładem adaptacji cyfrowej zacierającej granice między dotychczasowymi dyskursami, formami medialnymi i sztukami. Istotne przy tym jest to, że akt znoszenia granic i przetwarzania wpisuje się $\mathrm{w}$ istotę cyfrowego działania tekstowego, nie jest zdarzeniem jednorazowym czy nawet powtarzalnym, ale techniką i zasadą tego środowiska.

$$
* * *
$$

Sztuka jest formą i działaniem twórczym na formie, której nieustanne przekształcanie jest życiodajną jej siłą. Konstytutywną zasadę działań artystycznych stanowi nieustanne przekraczanie istniejących granic (zewnętrznych i wewnętrznych), przełamywanie ustalonych norm, które lokują sztukę w przestrzeni bezpiecznej stagnacji hamującej jej rozwój. Niwelowanie granic możliwe jest dzięki istnieniu w przestrzeni różnych sztuk, ale też różnych dyskursów analogicznych struktur tekstowych, u których podstaw leżą ujawniające się w nich operacje myślowe. Przełamywanie granic zewnętrznych wiąże się dla sztuki z wkraczaniem w obszary różnoznakowych dyskursów, w których dominują inne funkcje niż estetyczna. W tym przypadku to funkcje organizujące dyskurs wyznaczają granice. Ponieważ

${ }^{18} \mathrm{O}$ narracji interpretacyjnej i alternatywnej zob. tamże, s. 264-265, 275-290. 
wprowadzenie elementów jednego dyskursu do drugiego wiąże się z podporządkowaniem ich zasadom tego dyskursu, wprowadzanie w przestrzeń sztuki tego, co zewnętrzne, oznacza jego artystyczne przemodelowanie.

Problemu zmiany dominujacej funkcji nie ma w przypadku przełamywania granic wewnętrznych sztuki. Granice dotyczą tu materii sztuki, semiosfer, dlatego nawiązania i odniesienia wymagają ich naruszenia - zwykle metaforycznego. Inaczej jest w przypadku sztuki cyfrowej, która lokuje przedmioty wszystkich sztuk poza granicami dotychczasowych materii $\mathrm{w}$ środowisku cyfrowym. Jednocześnie, co istotne, sztuka ta nie rezygnuje z ontyczności dotychczasowych materii, wręcz przeciwnie - dopiero ich brak sprawia, że docenia ich wagę - czyni je własnym tematem, przedmiotem artystycznego namysłu.

Działania tekstowe, takie jak adaptacja, przekład, parafraza, użycie nazywające formy przekształceń różniące się między sobą dominantą która je organizuje, w przestrzeni sztuki stają się narzędziem i rezultatem twórczej zmiany - są formami artystycznego przetworzenia. Dotyczy to również działań tekstowych, które w innym środowisku dyskursywnym nie deklaruja przekształcania swojego odniesienia, jak ma to miejsce w przypadku reprezentacji, a które w przestrzeni sztuki zyskują dyspozycję twórczą.

\section{BIBLIOGRAFIA}

Balcerzan E., Poetyka przektadu artystycznego, [w:] E. Balcerzan, Oprócz głosu. Szkice krytycznoliterackie, Warszawa 1971.

Baudrillard J., Spisek sztuki. Iluzje i deziluzje estetyczne z dodatkiem wywiadów o Spisku sztuki, przeł. S. Królak, Warszawa 2006.

Bazin A., O film nieczysty - obrona adaptacji filmowej, [w:] A. Bazin, Film i rzeczywistość, wybór tekstów, przeł. B. Michałek, Warszawa 1963.

Choczaj M., O adaptacji, ekranizacji, przekładzie intersemiotycznym i innych zmartwieniach teorii literatury, filmu i mediów, „Przestrzenie Teorii” 2011, nr 16.

Deleuze G., Różnica i powtórzenie, przeł. B. Banasiak, K. Matuszewski, Warszawa 1997.

Eco U., Lector in fabula. Wspótdziałanie w interpretacji tekstów narracyjnych, przeł. P. Salwa, Warszawa 1994.

Helman A., Adaptacja - podstawowa technika twórcza kina, [w:] A. Helman, Intermedialność w kulturze końca XX wieku, red. A. Gwóźdź, S. Krzemień-Ojak, Białystok 1998.

Helman A., Twórcza zdrada. Filmowe adaptacje literatury, Poznań 1998.

Hendrykowski M., Adaptacja jako przekład intersemiotyczny, „Przestrzenie Teorii” 2013, nr 20.

Hopfinger M., Adaptacje filmowe utworów literackich. Problemy teorii i interpretacji, Wrocław 1974.

Jackiewicz A., Film jako powieść XX wieku, Warszawa 1968. 
Jenkins H., Ford S., Green J., Rozprzestrzenialne media. Jak powstaja wartości i znaczenia w usieciowionej kulturze, przeł. M. Wróblewski, Łódź 2018.

Markowski M.P., Interpretacja i literatura, „Teksty Drugie” 2001, nr 5.

Miczka T., Adaptacja, [w:] Stownik pojęć filmowych, red. A. Helman, t. 10, Kraków 1998.

Osadnik M.W., Adaptacja filmowa jako przektad, [w:] Kino wedtug Alicji, red. W. Gwóźdź, T. Lubelski, Kraków 1995.

Szczęsna E., Cyfrowa semiopoetyka, Warszawa 2018.

Szczęsna E., Poetyka reklamy, Warszawa 2001, 2003.

Uspienski B., Strukturalna wspólnota różnych sztuk. Ogólne zasady organizacji dzieła malarskiego i literackiego, przeł. P. Fast, [w:] B. Uspienski, Poetyka kompozycji. Struktura tekstu artystycznego i typologia form kompozycji, Katowice 1997.

Wagner G., The Novel and the Cinema, Rutherford-New York 1975.

Wysłouch S., Ekfraza czy przekład intersemiotyczny, [w:] Ruchome granice literatury, red. S. Wysłouch, B. Przymuszała, Warszawa 2009.

Wysłouch S., Literatura i obraz. Tereny strukturalnej wspólnoty sztuk, [w:] Intersemiotyczność. Literatura wobec innych sztuk (i odwrotnie), red. S. Balbus, A. Hejmej, J. Niedźwiedź, Kraków 2004.

Ziomek J., O wspótczesności retoryki, [w:] J. Ziomek, Prace ostatnie, Warszawa 1994. 
